\title{
THE TOXICITY OF SODIUM NITROPRUSSIDE
}

\author{
Leila Greiss, N.A.G. Tremblay, and D.W. Davies
}

Sodium Nitrophusside $\left(\mathrm{Na}_{2} \mathrm{Fe}(\mathrm{CN})_{5} \mathrm{NO}\right)$ has been used for the treatment of hypertensive crises ${ }^{1}$ to provide controlled hypotension during anaesthesia ${ }^{2}$ to improve left ventricular function, ${ }^{3}$ and to treat ergotamine-induced peripheral ischaemia. ${ }^{4}$

The action of sodium nitroprusside is one of direct dilatation of the vasculature. Sodium nitroprusside acts predominately on the tonic smooth muscle of the blood vessels. The nitroso group (-NO) interferes with excitation-contraction coupling by inhibiting both the influx of and the intracellular activation of calcium ion."

Intravenous infusion of sodium nitroprusside produces an immediate and profound response which is evanescent, necessitating the continuous infusion of a weak solution ( 0.01 per cent sodium nitroprusside) at a rate gradually increased to provide the hypotensive response required. Constant vigilance to the dose response characteristics of the patient and continuous direct intra-arterial pressure monitoring are mandatory.

\section{Adverse Reactions to Sodium Nitroprusside}

A review of the reported experience of the use of sodium nitroprusside is instructive and permits a safe and more rational use of a potentially lethal drug.

With disciplined use sodium nitroprusside has proved to be a valuable pharmacological agent. However, in the past two years, three deaths ${ }^{(i-s}$ and one case of severe acidosis" associated with the use of sodium nitroprusside have been reported. Each of these incidents has been associated with an abnormal response to sodium nitroprusside. McDowall, et al. ${ }^{10}$ in England have reported on the toxicity of sodium nitroprusside in baboons. Davies, et al. ${ }^{11}$ have reported on the metabolic changes observed during abnormal responses to this drug in children and adolescents.

The patient of Jacki was a previously healthy middle-aged man undergoing stapedectomy. This patient exhibited early resistance to the hypotensive effects of sodium nitroprusside. The average rate of infusion is calculated to have been approximately $370 \mu \mathrm{g} / \mathrm{kg} / \mathrm{min}$ to a total of $750 \mathrm{mg}$. No acid-base evaluations of the patient were made until the heart arrested during the early post-operative period. At that time the patient exhibited a severe metabolic acidosis.

The patient of Merrifield, et al. ${ }^{7}$ was a 20 -year-old previously healthy male undergoing mandibular osteotomies. This patient exhibited tachyphylaxis to sodium nitroprusside within the first hour of its infusion. Sodium nitroprusside was infused

From the Department of Anaesthesia, University of Toronto, Toronto.

Address requests for reprints to: Dr. D.W. Davies, Department of Anaesthesia, The Hospital for Sick Children, 555 University Avenue, Toronto, Ontario, Canada. M5G IX8 
at an average rate calculated to have been $33 \mu \mathrm{g} / \mathrm{kg} / \mathrm{min}$ to a total of $750 \mathrm{mg}$ in five hours. The first acid-base evaluation of the patient was made at the time of his cardiac arrest in the early post-operative recovery period. A severe metabolic acidosis was apparent.

The fatal case of Davies, et al. ${ }^{8}$ was a previously healthy 14 -year-old male undergoing mandibular osteotomies. This patient showed almost immediate resistance to the hypotensive effects of sodium nitroprusside. He received $400 \mathrm{mg}$ in $80 \mathrm{~min}-$ utes at an average rate of $120 \mu \mathrm{g} / \mathrm{kg} / \mathrm{min}$. The patient's heart arrested within thirty minutes of discontinuing the sodium nitroprusside infusion and at that time had a severe metabolic acidosis.

The case of severe metabolic acidosis associated with the use of sodium nitroprusside reported by $\mathrm{McCrae}$, et al." was a 42-year-old previously healthy female undergoing stapedectomy. This patient exhibited resistance to the hypotensive action of sodium nitroprusside. The sodium nitroprusside was infused at an average rate calculated to have been approximately $43 \mu \mathrm{g} / \mathrm{kg} / \mathrm{min}$ to a total of $250 \mathrm{mg}$ in 90 minutes. The acid-base status in this patient was first measured about one hour post-operatively because of tachypnoea and an incomplete and bizarre neurological recovery from anaesthesia. She was found to have a severe metabolic acidosis.

McDowall ${ }^{10}$ has shown that four of eight baboons were resistant to the hypotensive action of sodium nitroprusside. These animals which received high doses of sodium nitroprusside, calculated to be in excess of $80 \mu \mathrm{g} / \mathrm{kg} / \mathrm{min}$, incurred a severe metabolic acidosis and a marked decrease in cerebral oxygen uptake. These baboons did not survive.

Abnormal responses to sodium nitroprusside in children and adolescents have been reported in some detail by Davies, et al. ${ }^{11}$ and the experience of these workers can be summarized as follows.

Four distinct responses to the infusion of sodium nitroprusside were recognized:

1. A constant response to low doses of sodium nitroprusside $(<10 \mu \mathrm{g} / \mathrm{kg} / \mathrm{min})$ which is the usual clinical experience.

2. A constant response to high doses of sodium nitroprusside $(>10 \mu \mathrm{g} / \mathrm{kg} / \mathrm{min})$.

3. A tachyphylaxis to sodium nitroprusside apparent in 30 to 60 minutes of starting the infusion.

4. A definite resistance to the action of sodium nitroprusside which becomes apparent within 5 to 10 minutes of starting the infusion. Resistance is defined ${ }^{11}$ as an inability to attain or maintain safe minimal levels of systolic blood pressure even with increasing doses of sodium nitroprusside.

These latter three abnormal responses may occur in either sex and are potentially lethal. Tachyphylaxis or the need for a constant high dose of sodium nitroprusside appears to occur in about 30 per cent of the paediatric population. Each of these abnomal responses was associated with (a) an increasing metabolic acidosis, which can be severe, (b) an increasing mixed venous oxygen tension and (c) a decreasing arterial-mixed venous oxygen content difference. These metabolic 
changes are thought to be due to cyanide (an intermediate metabolite of nitroprussicle metabolism) intoxication and cellular hypoxia. One lethal case ${ }^{3}$ associated with the use of sodium nitroprusside revealed lethal levels of cyanide in the blood $(0.5 \mathrm{mg} / 100 \mathrm{ml})$ and no measurable levels of thiocyanate (the relatively innocuous end metabolite of nitroprusside metabolism) in blood or urine.

\section{The Toxicity of Sodium Nitroprusside}

The toxicity of nitroprusside appears to be related to the rate of infusion rather than the total amount given. Amounts in excess of $2.7 \mathrm{gm}$ have been given continuously over a five-day period ${ }^{12}$ without mishap whereas $400 \mathrm{mg}$ given over 80 minutes has been fatal. ${ }^{8}$

The fastest safe rate of infusion for sodium nitroprusside is not known because the dynamics of its metabolism are not yet determined. Taylor, et al. ${ }^{13}$ have infused sodium nitroprusside at rates calculated to be as high as $40 \mu \mathrm{g} / \mathrm{kg} / \mathrm{min}$ with no reported ill effects; however, no clinical or metabolic parameters were recorded other than blood pressure and pulse responses before, during and after the infusion of sodium nitroprusside.

The maximal rate of $1.6 \mathrm{mg} / \mathrm{kg} / \mathrm{hr}(26.6 \mu \mathrm{g} / \mathrm{kg} / \mathrm{min})$ suggested by $\mathrm{McDowall}^{10}$ is far too high. Any rate of infusion of sodium nitroprusside above $10 \mu \mathrm{g} / \mathrm{kg} / \mathrm{min}$ usually has been associated with at least adverse metabolic disturbances, or more often, disaster.

\section{Possible Mechanisms of Abnormal Responses to Sodium Nitroprusside}

Sodium nitroprusside reduces systemic and pulmonary arterial and venous pressures by direct vasodilation. Hypotension produced in this manner can activate renin-angiotension relcase. Angiotensin causes vasoconstriction and increases cardiac rate and contractility. These responses will tend to antagonise the hypotensive action of sodium nitroprusside. Possibly these sequences of physiological responses to sodium nitroprusside may be responsible for the necd for high doses ( $>10 \mu \mathrm{g}$ ) $\mathrm{kg} / \mathrm{min}$ ) of sodium nitroprusside to produce the hypotensive effect required. The judicious use of propanalol will block all the compensatory physiological responses including renin release.

There is some evidence to suggest that tachyphylaxis to sodium nitroprusside is related to abnormalities of thiosulphate metabolism or depletion of endogenous thiosulphate supplies. ${ }^{6.8}$

If endogenous thiosulphate is present in reduced amounts, then the conversion of the intermediate metabolite (cyanide ion) to the end metabolite (thiocyanate ion) is reduced. The availability of thiosulphate is the rate-limiting factor in the conversion of cyanide to thiocyanate by tissue rhodanese. Consequently cyanide ion will accumulate with the continued infusion of sodium nitroprusside if there is insufficient thiosulphate.

The hypothesis that resistance to the hypotensive effect of sodium nitroprusside represents antagonism of the vasodilator action of this drug by increasing amounts of cyanide is presently being tested. ${ }^{14}$

Further studies in this area are needed before one can reasonably rely on thiosulphate replacement as a safe and rational concommitant therapy when using 
sodium nitroprusside. Even if thiosulphate depletion is confirmed it may well prove less than satisfactory therapy as cyanide-thiocyanate metabolism is an intracellular enzymatic process and only very small fractions of exogenous thiosulphate will penetrate cell membranes.

\section{The Rational and Safe Use of Sodium Nitroprusside}

The following are suggested as mandatory disciplines to adhere to when using the drug.

1. Absolute contraindications to its use exist in patients who have (1) Resistance to sodium nitroprusside, (2) Leber's hereditary optic atrophy, (3) tobacco ambylopia, (4) severe liver disease, (5) severe renal disease, 6) malnutrition, (7) vitamin $\mathrm{B} 12$ deficiency, (8) hypothyroidism.

2. The use of solutions of not more than 0.02 per cent sodium nitroprusside suitably protected from light and heat.

3. The administration of infusions of sodium nitroprusside by a separate intravenous infusion by a microdrip or infusion pump.

4. Direct and continuous intra-arterial pressure monitoring.

5. Frequent (half-hourly) arterial acid-base determinations.

6. Constant attention to the patient's dose-response characteristics, particularly in the first thirty minutes.

7. If infusion rates are in excess of $10 \mu \mathrm{g} / \mathrm{kg} / \mathrm{min}$ determine the nature of the response: constant, tachyphylactic or resistant?

8. If constant or tachyphylactic temporarily discontinue the sodium nitroprusside, administer another hypotensive agent e.g. pentolinium $0.1-0.2 \mathrm{mg} / \mathrm{kg}$. After five minutes re-start the infusion of nitroprusside if further hypotension is required. The new infusion rate is usually $10-20$ per cent of the original requirements of nitroprusside. ${ }^{15}$

Altemately, one can use propanalol. If the infusion of sodium nitroprusside evokes a tachycardia, administer propanalol intravenously by increments, until the apex rate is reduced to pre-tachycardia levels. The total amount of propanalol required is usually less than $0.5 \mathrm{mg}(0.007 \mathrm{mg} / \mathrm{kg})$. This also reduces the dose of sodium nitroprusside to $10-20$ per cent of the previous requirements. ${ }^{16}$

9. Resistance to sodium nitroprusside is an absolute indication to abandon the use of the drug and to use a different drug altogether.

10. Maintain nomothermia throughout. ${ }^{\text {s }}$

11. Prolonged infusions of sodium nitroprusside even at low dosage should be monitored by daily thiocyanate measurements of the patient's blood. If levels above $10 \mathrm{mg}$ of thiocyanate per $100 \mathrm{ml}$ patient blood are recorded, then the sodium nitroprusside should be discontinued. ${ }^{17}$

12. Whenever using sodium nitroprusside one must have available cyanide antidote therapy." This includes (1) inhalations of amyl nitrite every tivo minutes, (2)

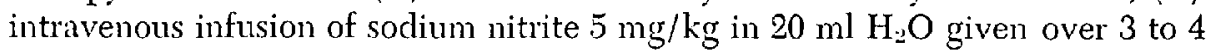
minutes, (3) intravenous infusion of sodium thiosulphate $150 \mathrm{mg} / \mathrm{kg}$ in $50 \mathrm{ml}$ water over 15 minutes. The nitrites will produce methaemoglobin which has a 
much higher affinity for cyanide than cytochrome oxidases. Thiosulphate is given to supply necessary substrate to convert cyanide to thiocyanate. Hydroxocobalamin, if available, can be given $0.1 \mathrm{mg} / \mathrm{kg}$ which will combine with cyanide and render it inactive.

\section{RÉSUMÉ}

Le nitroprussiate de soude est utilisé comme vasodilatateur puissant chez l'homme depuis 1929. A partir de communications à propos de trois décès reliés au NPS on retient: l'acidose grave et le taux de dosage élevé de nitroprussiate de soude. Ces derniers effets peuvent se rencontrer chez des cas de réponses anormales, nonmortelles au nitroprussiate de soude.

La réponse à l'action du nitroprussiate de soude est l'une des suivantes:

Normale 1. vasodilation à bas taux de dosage $(<10 \mu \mathrm{g} / \mathrm{kg} / \mathrm{min})$

Anormale 2. vasodilatation à haut taux de dosage $(>10 \mu \mathrm{g} / \mathrm{kg} / \mathrm{min})$

3. tachyphylaxie

4. résistance

La manifestation anormale de l'action du nitroprussiate de soude est une des suivantes:

- reaction physiologique excessive (rénine-angiotensine-aldostérone), traité par blocage beta ou ganglioplégie;

- acidose et accumulation de cyanure de la biotransformation du NPS, traité comme une intoxication au cyanure.

On donne le canduite à suivre pour l'ultilisation sùre de nitroprussiate de soude les contre-incations, ladministration du nitroprussiate de soude, la surveillance requise, la conduite à tenir face aux reactions anormales.

\section{REFERENCES}

1. Jornsox, C.C. The actions and toxicity of sodium nitroprusside, Arch. Int. Phamacodyn. Therap, 35: 480 (1929).

2. Moraca, P.P., Bitte, E.M., Hale, D.E., et al. Clinical evaluation of sodium nitroprusside as a hypotensive agent, Anesthesiology 23: 193 (1962).

3. Chatterjee, K., Pararley, W.W., Ganz, et al. Hemodynamic and metabolic responses to vasodilator therapy in acute myocardial infarction, Circulation 48: 1183 (1973).

4. Carliner, N.H., Denune, D.P., Finch, C.S., et al. Sodium nitroprusside to treat ergotamine induced peripheral ischemia, J.A.M.A. 227: 3, 308 (1974).

5. Kreye, V.A.W., BAros, G.P., Lütir, J.B., et al. Mode of action of sodium nitroprusside on vascular smooth muscle, Naunyn-Schmiedeberg's Arch. Pharmacol. 288: 381 (1975).

6. JACK, R.D. Toxicity of sodium nitroprusside, B.J.A. 46: 952 (1974).

7. Merrifield, A.J. \& Bluxdell, M.D. Toxicity of sodium nitroprusside, B.J.A. 46: 324 (1974).

8. Davies, D.W., Kadar, D., Steward, D.J., et al. A sudden death associated with the use of sodium nitroprusside for induction of hypotension during anaesthesia, Canada. Anaesth. Soc. J., 22: 547 (1975).

9. MCCrae, W.R. \& Owen, MARY Severe metabolic acidosis following hypotension induced with sodium nitroprusside, B.J.A. 46: 795 (1974).

10. MeDowall, D.G., Kenney, N.P., Turner, J.E., et al. The toxicity of sodium nitroprusside, B.J.A. 46: 327 (1974). 
11. Davies, D.W., Greiss, L., \& Kanan, D. Metabolic observations during normal and abnormal responses to sodium nitroprusside during anaesthesia in children, Canada. Anaesth. Soc. J. $22: 553$ (1975).

12. Vesey, C.J., Cole, P.V., Linvel, J.C., et al. Some metabolic effects of sodium nitroprusside in man, B.M.J. $2 ; 140$ (1974).

13. Taylon, T.H., Styles, M., \& Lampins, A.J. Sodium nitroprusside as a hypotensive agent in general anaesthesia, B.J.A. 42: 859 (1970).

14. Davies, D.W., Tremblay, N.G., \& Kadar, D. Work in progress, Research Institute of the Hospital for Sick Children, Toronto.

15. Davies, D.W. - personal communication, The Hospital for Sick Children, Toronto.

16. Greiss, L. - personal communication, Sunnybrook Medical Centre, Toronto.

17. Tuzer, I.H. Sodium nitroprusside: A review of its clinical effectiveness as a hypotensive agent. J. Clin. Pharmacol. 494 (1974). 